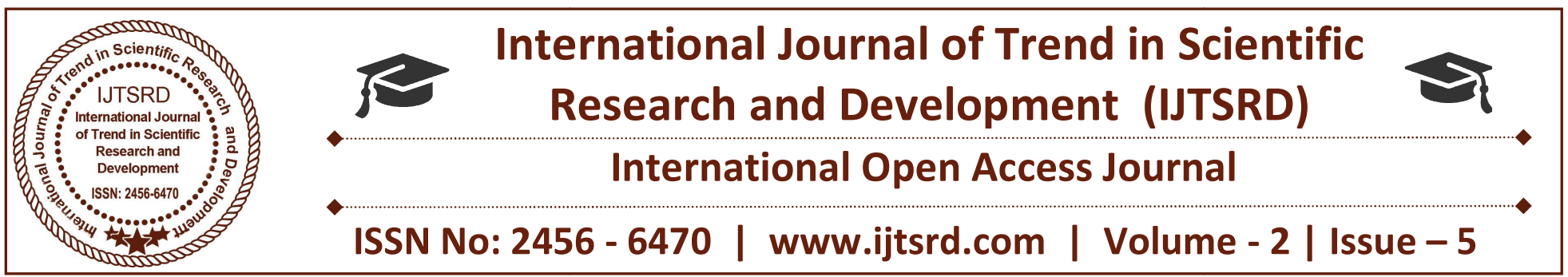

\title{
The Process of Impeachement of Judges
}

\author{
Dharmesh Jadoun \\ B.A., LL.B (Hons), Indore Institute of Law \\ Indore, Madhya Pradesh, India
}

\begin{abstract}
India needs a less cumbersome way to impeach judges and make the judiciary more accountable. The Judicial Standards and Accountability Bill should be revived. Over the past seven decades, the provision in India's Constitution relating to the impeachment of judges in the higher judiciary has failed to give satisfactory results. Most debates around abortive impeachment motions made in the past have centred around the need for India to evolve an impeachment mechanism that is less cumbersome. But a bill introduced in Parliament that attempts to make the judiciary accountable - the Judicial Standards and Accountability Bill - has been gathering dust over the
\end{abstract} last few years.

\section{Introduction ${ }^{1}$}

The Indian Judiciary is remains of the legal system that was established by the British Raj based on the English common law. Having customs, precedents, and legislature. The Constitution of India come into force on 26th January 1950, and the distance we have travelled since . lays down the law of the land. The Supreme Court of india is the highest court in the land, followed by the various High Courts and District level courts. The Indian Constitution was drafted with parts from Irish, French, american and British laws and additionally adheres to the human rights code set forth by the international organization. Members of the Judiciary are independent of the legislature and executive body Historically, India was governed by the Arthashastra and Manusmriti - two ancient texts that provided legal guidance.

\footnotetext{
${ }^{111}$ https://www.thehindu.com/news/national/list-of-judges-whofaced-impeachment-proceedings/article18578156.ece
}

The question of removal of a Judge before the age of retirement is an important one as it has a significant bearing on the independence of the judiciary. If a Judge of he Supreme Court could be removed by the Executive without much formality, then it can be imagined that the Court would lose its independence and become subject to the control of the Executive.

In every democratic country swearing by the Rule of Law, therefore, special provisons are made making removal of judges an extremely difficult exercise. In Britain for example, Judges hold office during good behaviour and can be removed on an address from both Houses of Parliament. In the U.S.A., Supreme Court Judge holds office for life and is removable only by the process of impeachment in case of treason, bribery or other high crimes. Provision has however been made by law for voluntary retirement on full salary after ten years of service and attainment of the age of seventy

The Constitution of India also makes a provision for the removal of a Supreme Court Judge. he may be removed from office by the President on an address by both houses of Parliament presented in the same session for proved misbehaviour or incapacity. The address must he supported by a majority of the total membership in each House, and also by a majority of not less than two thirds of the members of each House present and voting

The word proved in this provision indicates that the address can be presented by Parliament only after the alleged charge of misbehaviour or incapacity against Judge has been investigated, substantiated and established by an impartial tribunal. The constitutional provision does not prescribes how this investigation is to be carried on. It leaves it to 
Parliament to settle and lay down by law the detailed procedure according to which the address may be presented and the charge of misconduct or incapacity against the judge investigated and proved

\section{Procedure for the removal of judges in India.}

Parliament has enacted the necessary law for this purpose. The Judges (Inquiry) Act, 1968 now regulates the procedure for investigation and proof of misbehaviour or incapacity of a supreme court judge for presenting an address by the house of parliament to the president for his removal.

The procedure for the process is as follows: a notice of a motion for presenting such en address may be given by 100 members of the Lok Sabha or 50 members of the Rajya Sabha. The Speaker or the Chairman may either admit or refuse to admit the motion. If it is admitted, then the Speaker/chairmen is to constitute a committee consisting of a supreme Court Judge, a Chief Justice of a High Court and a distinguished jurist if the notice for the motion are given on the same day on both the houses the Committee of Inquiry is to be constituted jointly by the Speaker and the Chairman.

The Committee of inquiry is to frame definite charges against the Judge on the basis of which the investigation is proposed to be held and give him a reasonable opporturity of being heard including crossexamination of witnesses. If the charge is that of physical or mental incapacity, the Committee may arrange for the medical examination of the judge by a medical board appointed by the Speaker/ chairman or exam both as the case may be.

The report of the Committee is to be laid before the concerned House or Houses. If the Committee exonerates the Judge of the charges laid against him, then no further action is to be taken on the motion for his removal. if, however, the Committee finds the Judge to be guilty of misbehaviour, or suffering from an incapacity, the House can take up the consideration of the motion. On the motion being adopted by both the Houses according to Art. 124(4), noted above, an address may be presented to the president for the removal of the Judge. Rules under this Act are to be made by a committee consisting of 10 members from the Lok Sabha and 5 members from the Rajya Sabha.

\section{Relation of Indian provisions for removal of judges to the English provisions}

It can be seen that the constitutional provision in India for the removal of a Supreme Court Judge is modelled on the English provision, though the former is somewhere rigid than the latter insofar as-

(i) it requires a special majority in both houses while in England no such majority prescribed

(ii) while in India the grounds have been specified on which an address for the removal of a Judge can be presented there is no such procedure in England

(iii) in India, there is provision for investigation and proof of the grounds before presenting an address, no such procedure exist in England for the removal of judges therefore, it appers that the procedure for removal of judges in England is more flexible than that of india ${ }^{2}$

The provision in England for the outlined above for the removal of a Supreme Court Judge was activated in 1991. For the first time since the constitution come into force, the above- mentioned ${ }^{3}$ procedure to removal of the Supreme Court Judges was put in motion in 1991 Steps were in initiated to remove a Supreme Court Judge on charges of misconduct or to his appointent when he was the Chief Justice of a High Court. 108 members of the Ninth Lok Sabha gave notce to the Speaker of a motion for presenting an address to the President for removal of justice Ramaswarni the Supreme Court.

The charges against him was that he committed financial irregularities while he was the Chief Justice of Punjab and Haryana High Court. The Speaker of the Lok Sabha admitted motion on 12th March, 1991, and proceeded to constitute an Enquiry Committee consisting of Justice P.E. SAWANT, a sitting Judge of the Supieme Court chief justice DESNI of the Bombay heigh Cout and Mr. CHINNAPTA REDDY a retired supreme court judge as a dintinguised jurist.

\section{Rules made under the constitution after reading the judges inquiry act 1964 in the ramaswamy case}

After reading the constitutional provisions and the provisiors of the Judges (Inquiry) Act and the rules made theneunder, the Court pointed out. that if the

\footnotetext{
${ }^{2}$ https://www.quora.com/What-is-the-procedure-to-remove-a-

Supreme-Court-Judge-in-India

${ }^{3}$ Dr JN Pandey, constitutional law of India, 533, (54 ${ }^{\text {th }}$ Ed,2017)
} 
Inquiry committee reches to the verdict that of 'not guilty' either unanimously or majority the matter ends there and Parliarnent is not required to take up the motion of renmova for consideration

This is means that the Inquiry Committce is the sole and final arbiter on the question of removal of judges where the finding reach by the committee, whther unanimously or by majority, is that the Juge is not guilty. This indicates thet there can be no judicial review where the Inquiry Committee makes a finding that the Judge is no 'guilty' of any mistehaviour. In such a situation, no question arises of furnishing a copy of the report of the Committee to the concerned Judge.

In case, the Inquiry Committee finds the judge guilty, then the matter goes to Parliament. The Supreme Court has to the conclusion that under Art. 124(4), a full consideration on merits, including correctness of the finding of guilty' made by the Inquiry Committee on the basis of the materials before the Parliament is contemplated during the Parliamentary part of the process of removal of a judge

This means that despite the finding of guilty' by the Committee the Parliament may decide, after considering the matter, no to adopt the motion for removing the judge. This leads to the conclusion that the cocerned Judge should also have an opporumity to comment on the finding by the Inquiry Committee for this purpose therefore, the Speaker Chairman of the House his to supply a copy of the Inquiry Committee's report to the concerned judge while causing it to laid before the parliament under S. 4(3) of the Act

As regards judicial review, the Court has ruled that if Parliament does not adopt the motion for removal of the Judge, the process ends there with no challenge available to anyone The judicial review of the finding of guilty made by the inquiry Committee may he permissable on limited ground "pertaining only to legality" but only after the making of the order of the removal by the President in case the Parliament adopts the motion by the requisite majority concerned Judge between the time of conclusion of the inquiry by the Committee and making of the order of removal by the President would be premature and is unwaranted in the constitutional scheme.

The Supreme Court has ruled that the Inquiry Committee appointed under the Judges (Inquiry) Act cannot be treated as a tribunal for the purposes of Art. 136 because the report finding the Judge guilty of misbehavour is "in the nature of recommendation for his removal which may or may not be acted upon by the Parliament" Since the Committee holding that the Judge is guilty of any misbehaviour is not "final and conclusive", "it is legally not permissible to hold that the Committee is a tribunal under Art. 136 of the Constitution. This means that an appeal cannot be filed in the Supreme Court from the Inquiry Commitee under Art. 136.

This judgment has seeds of confrontation between the Supreme Court and Parliament, Ordinarily, after Parliament has taken a decision to remove the Judge, on the basis of the report of the Committee of Inquiry, the matter should come to an end. As the Court has said itself, if the Inquiry Committee report is favourable to the concerned Judge, the matter ends there and the Parlliament cannot take any further action in the matter. If, however, the report of the Inquiry Committee goes against the Judge then, only Parliament: can take action to remove him after giving him a hearing on the inquiry report

Once parliament has passed the resolution of removing the Judge after following the due procedure and the President assents to the motion, the Judge stands removed and there appears to be no need for any judicial review thereafter. Otherwise, there is a chance of controvery arising between the judiciary and the parliament . in the case the judicial review can only be procedural grounds not on the merits of the grounds the removal

The President cannot remove a Supreme Court Judge cxcept in accordance with the procedure laid down in Art. 124(4). Thus, the President cannot remove a Judge unless each House of Parliament passes an address for the removal of the Judge supported by a majority of the total membership of the House and by a majority of not less than two-third of members present and voting on the ground of proved misbehaviour and incapacity. Unless such an address is presented to the President in the same session by the two Houses, the President is not empowered to remove a Judge 
Scope of the ${ }^{4}$ word 'misbehaviour' used in article 124(4)

The word 'misbehavior; used in Art. 124(4), "is a vague and elastic word and embraces within its sweep different facts of conduct as opposed to good conduct" Literally misconduct means wrong conduct or improper conduct. Guarantee of a tenure to a Judge, and its protection $b$ by the Constitution does not mean giving sanctuary for corruption or grave misbehaviour. But, at the same time, every action or omission by a Judge in the performance of his duties which may not be a good conduct neccessarily, may not be regarded misbehaviour for purposes of Art. 124(4) indictable by impeachment. Error in judgment, however gross, cannot amount to misbehavior

\section{Judges on who had faced the impeachment procedure}

\section{Justice V. Ramaswami}

Justice V. Ramaswami has the dubious distinction of being the first judge against whom impeachment proceedings were initiated. In 1993, the motion was brought up in Lok Sabha, but it failed to secure the required two-thirds majority.

Justice Ramaswami was caught in a controversy for spending extravagantly on his official residence during his tenure as Chief Justice of Punjab and Haryana during 1990. The Supreme Court Bar Association even passed a resolution calling for his impeachment.

\section{Soumitra Sen}

Justice Soumitra Sen of the Calcutta High Court in 2011 avoided the ignominy of becoming the first judge to be impeached by Parliament by tendering his resignation.

He did so after the Rajya Sabha had passed the motion making him the first judge to have been impeached by the Upper House for misconduct. Justice Sen was found guilty of misappropriating Rs 33.23 lakh under his custody as a court-appointed receiver in the capacity as a lawyer, and misrepresenting facts before a Calcutta court in a 1983 case

\section{P.D Dinakaran}

Justice P.D. Dinakaran, Chief Justice of the Sikkim High Court, against whom the Rajya Sabha Chairman had set up a judicial panel to look into allegations of corruption, resigned in July 2011, before impeachment proceedings could be initiated against him.

Corruption, land-grab and abuse of judicial office were among the 16 charges framed against Justice Dinakaran

\section{J.B. Pardiwala}

In 2015, a group of 58 Rajya Sabha MPs moved an impeachment notice against Justice J.B. Pardiwala of the Gujarat High Court for his "objectionable remarks on the issue of reservation."

The MPs, in their petition, said Justice Pardiwala's comments on reservation for Scheduled $\mathrm{C}^{5}$ astes and Scheduled Tribes, while giving a ruling in a case against Patidar leader Hardik Patel, were objectionable. The specific objection seemed to be connected to the observations made by the judge in paragraph 62 of the judgment.

"If I am asked by anyone to name two things which have destroyed this country or rather have not allowed the country to progress in the right direction, then the same is, (i) Reservation and (ii) Corruption. It is very shameful for any citizen of this country to ask for reservation after 65 years of Independence. When our Constitution was framed, it was understood that reservation would remain for a period of 10 years, but unfortunately, it has continued even after 65 years of Independence," he had said.

Hours after the impeachment notice was sent to Hamid Ansari, the judge removed the wording from his judgment

\section{Justice Deepak Misra}

Chief Justice of India Dipak Misra, who is due to retire on October 2, is the sixth judge to face impeachment for removal from office, though no judge has been impeached to date. The proceedings so far have been initiated against a Supreme Court judge and four High Court judges

\footnotetext{
${ }^{4} \mathrm{http}$ ://www. freepressjournal.in/analysis/impeachment-motionsixth-judge-to-face-impeachment-but-none-removed-thusfar/1261939
}

\footnotetext{
${ }^{5}$ http://www.thehindu.com/news/national/list-of-judges-whofaced-impeachment-proceedings/article18578156.ece
} 


\section{Whether India needs a change a less cumbersome way to impeach to make judiciary more accountable}

Over the past seven decades, the provision in India's Constitution relating to the impeachment of judges in the higher judiciary has failed to give satisfactory results. Most debates around abortive impeachment motions made in the past have centred around the need for India to evolve an impeachment mechanism that is less cumbersome. But a bill introduced in Parliament that attempts to make the judiciary accountable - the Judicial Standards and Accountability Bill - has been gathering dust over the last few years.

The idea of giving security of tenure to the members of the higher judiciary is aimed at ensuring the independence of the judiciary, one of the pillars of democracy

Though the power to impeach a judge vests with Parliament, there are several safeguards in place before a judge can be removed from office. The requirement of a minimum number of MPs to sign the notice moving the impeachment motion, the admission of the motion by the chairman of the Rajya Sabha or Speaker of the Lok Sabha, the constitution of a three-member enquiry committee, a discussion on the committee's report in the House, and the final voting process ensure that no judge is victimised for the views expressed while discharging their duties.

\section{Past efforts at impeachment}

In the early 1990s, Justice V Ramaswami became the first judge in India against whom impeachment proceedings were initiated. He was accused of irregularities in the lavish expenditure he incurred as the Chief Justice of the Punjab and Haryana High Court. His case is evidence of the futility of attempting to impeach a judge of a higher court.

A group of lawyers had sent complaints about Ramaswami to Sabyasachi Mukherjee, the chief justice of India at the time. After a preliminary enquiry, Ramaswami in 1990 was advised to desist from discharging any judicial functions until his name was cleared. In 1991, a motion to impeach him was admitted by the Lok Sabha Speaker. A three-member committee constituted to investigate the matter found prima facie evidence of irregularities committed by the judge. A debate followed in Parliament, where Ramaswami fielded Kapil Sibal to address members of the House on his behalf. Voting on the motion was set for May 10, 1993.

On the day of the vote, PV Narasimha Rao, who led the ruling Congress at the time, issued a whip for part members to be present in the House, but not to vote. While 196 members voted for the motion to impeach Ramaswami, there were no votes in his favour. Despite this, the motion failed because the Constitution mandates that the success of an impeachment motion requires two-thirds of the members of the House to be present and voting. This did not happen.

Thus, a judge against whom Parliament members had voted, and with no one to support him, survived a bid to remove him from office.

\section{The politics on impeachement}

The impeachment of a member of the higher judiciary is always a political move. Last August, the Supreme Court of Bangladesh struck down the 16th amendment of its Constitution that had provided for the impeachment of members of the higher judiciary. The court gave a strange reason for its order. It said that the leader of the ruling party, which commands the majority in the House, has the final say in efforts to remove a judge, as she could issue a whip to members of her party to vote for the motion. This, according to Bangladesh's highest court, was a threat to the independence of the judiciary. Ironically, the Bangladesh Supreme Court's decision followed the Indian Supreme Court's 2015 judgment in which it struck down the National Judicial Appointments Commission Act. One hopes that the Supreme Court of India, in the light of present developments, does not follow Bangladesh's precedent of striking down the very process of impeachment.

The impeachment motion moved against Chief Justice of India Dipak Misra on April 20, by Opposition politic ${ }^{6}$ al parties led by the Congress, is now being described as political. But proponents of this bogey fail to realise that the world over, powers to impeach members of the judiciary have been vested with Parliament, and the motives of a particular move cannot be divorced from politics.

Whenever there is an unholy nexus between the higher judiciary and the ruling dispensation, any move

\footnotetext{
${ }^{6} \mathrm{https}$ //scroll.in/article/876552/opinion-it-is-time-to-push-forthe-passage-of-the-judicial-accountability-bill-in-india
} 
to remove the black sheep will always be branded as political. Considering the several safeguards provided by the Constitution (as interpreted by the Supreme Court), these accusations do not stand to reason.

\section{Futility of impeachment bid}

The cumbersome procedure of removing judges from their posts isn't likely to result in a sitting judge being impeached before their tenure is completed. For instance, the impeachment efforts against Justices PD Dinakaran and Soumitra Sen in 2011 did not go through because both resigned just before Parliament was to vote on the motion.

Eminent jurist Mohan Gopal, who was a member of the enquiry committee that was looking into the allegations against Dinakaran, even recommended that the last-minute resignation of judges facing impeachment should not make the impeachment motion infructuous, and that the Constitution should be amended to allow the impeachment procedure to be completed so that that this would at least enable the judge who is found guilty both by the enquiry committee and Parliament to be deprived of terminal benefits like pension. At present, judges who resign before they are impeached can still enjoy the perks attached to their retirement.
The move initiated against Misra was not to be completed before his superannuation in October. That is so because the lengthy and complex process of the impeachement that's why there is no judged in india who had been impeached. Because before the removal process of judge reach to its conclusion they either resingned or get retirement and enjoys all the perks and pension and the other benefits which the judges enjoys after retirement

Ultimately, it is evident that the provision to impeach a judge of the higher judiciary in India is not working, and one must revive the passage of the bill relating to judges accountability.

\section{Conclusion}

There is a Need to amend the provisons for the removal of judges so that its motive can served Constitution should be amended to allow the impeachment procedure to be completed. That would at least enable the judge who is found guilty both by the enquiry committee and Parliament to be deprived of terminal benefits like pension. At present, judges who resign before they are impeached can still enjoy the perks attached to their retirement. 